\title{
Programs and interventions for physical activity promotion in the Brazilian Unified Health System: a research object that starts to be unveiled
}

\author{
Programas e intervenções para promoção da atividade física no Sistema \\ Único de Saúde: um objeto de pesquisa que começa a ser desvelado
}

Mauro V. G. Barros, Flavio Renato Barros da Guarda, Wallacy Milton do Nascimento Feitosa, Emmanuelly Correia de Lemos, Caroline Ramos de Moura Silva

Encouraging the regular practice of physical activities is an important health promotion strategy and a concrete measure to implement the principle of health care comprehensiveness in the Sistema Unico de Saúde (SUS - Unified Health System) ${ }^{1}$. Although the body of evidence of benefits for health resulting from the adoption of active lifestyles has been consolidated ${ }^{2}$, the incorporation of this technology into public health actions and services in Brazil began to play a more important role in 2006, when the Politica Nacional de Promoção da Saúde (PNPS - National Health Promotion Policy) was implemented ${ }^{3,4}$. In fact, the PNPS directs the institutional SUS directives towards the operationalization of cross-sectional, integrated and intersectoral actions aimed at the improvement in quality of life of the Brazilian population. This policy, in addition to other endeavors, enabled the creation of a national network of projects geared towards the reduction in the prevalence of low levels of physical activity in this population ${ }^{5}$.

The effort involved in the investigations in the area of physical activity and health has focused on multiple themes, from studies on prevalence, those with an analytical and experimental approach that seek to more accurately identify the benefits of regular physical activity in different population groups, to others focused on aspects of professional qualification to work in the health sector ${ }^{2,6-8}$. In 2015 , the great number of studies published in Brazil allowed it to be the seventh country in number of publications on physical activity and public health among 217 countries $^{9}$, a fact recently revealed by the Global Observatory for Physical Activity (www.globalphysicalactivityobservatory.com). Although our country stands out in the world scientific scenario, specialists have emphasized the need to conduct more studies on programs and interventions aimed at the promotion of physical activity developed in the context of the Unified Health System ${ }^{7,10,11}$, a unique aspect in the Brazilian reality.

This supplement of the Brazilian Journal of Physical Activity and Health shows the innovative studies of researchers who have dealt with such question, with a particular focus on the nuances of programs and interventions developed in public health services of the state of Pernambuco that have not been sufficiently clarified. The reason why many studies have been conducted in this state is its 
participation and pioneering approach to the implementation of certain actions, such as the Programa Academia da Cidade (City Gym Program), an initiative that influenced the creation and development of related policies and similar programs in the entire country ${ }^{12}$.

This special issue includes studies that focused on the analysis of different research questions, all formulated so as to deal with all issues that frequently arise in the context of promotion of physical activity in health care. Although concentrated in the analysis of a more regional situation, the findings reported in the majority of studies may not be different from those observed in similar studies, performed in other regions of Brazil. Moreover, they contribute to the debate about the need for the continuous improvement in such initiatives.

Barros et al. described the methodological aspects used in the planning and execution of the Projeto SUS+Ativo (More Active Unified Health System Project Assessment of programs and interventions to promote physical activity in the Primary Health Care Network in the state of Pernambuco), performed in 2013 and 2014. This project covered from the development of instruments to the proposal of a methodological strategy to assess programs and interventions. Fonseca et al. showed the findings from a study that led to the creation and development of ways to use the short and long versions of the questionnaire known as Avaliação da Promoção de Atividades Físicas de Lazer para Gestantes (APAF|LG - Assessment of Promotion of Leisure Time Physical Activities for Pregnant Women).

Furthermore, this issue includes studies with physical education professionals that work in programs and interventions to promote physical activity, which describe the following: knowledge about the City Gym Program in Recife, Northeastern Brazil, among professionals working in Family Health Units; the characteristics of professionals working in programs of promotion of physical activity in primary health care in the state of Pernambuco; the contributions and challenges for the work of physical education professionals in Centros de Atenção Psicossocial (CAPS - Psychosocial Care Centers) in the city of Recife; self-perception of the objective, object and results of the work of physical education professionals who participate in the Programa Academia da Saúde (Health Gym Program) in the metropolitan area of Recife; and the inclusion of City Gym Program professionals in the context of Primary Care actions in Recife. The participation of health professionals and users in activities and their perception of programs of physical activity promotion in the sphere of primary health care are described in three studies. Finally, Andrade Silva et al. describe the aspects that characterize monitoring and assessment practices in interventions to promote physical activity developed in Primary Care in the state of Pernambuco, Northeastern Brazil.

The development of assessment instruments and the characterization of professionals, work processes and the perception of users and health professionals in different areas of work in the Unified Health System can contribute to the development of projects of intervention in the context of Primary Care. Additionally, it can help to encourage decision-making by professionals and managers and social control in terms of development and improvement in health actions, programs and policies aimed at the promotion of health, physical activity and comprehensive care in health care networks. Other studies must be performed to identify whether the assessment instruments proposed here can be applied in different contexts and whether the characteristics of physical education professionals, their work processes and the remaining participants' perception of interventions and programs differ from those observed in other locations. Of particular note is the 
recognition and financial support from the Conselho Nacional de Desenvolvimento Científico e Tecnológico (CNPq - National Council of Scientific and Technological Development) and Fundação de Amparo à Ciência e Tecnologia do Estado de Pernambuco (FACEPE - State of Pernambuco Scientific and Technological Support Foundation) for the development of these studies. Additionally, we would like to thank all researchers who contributed to the preparation of the manuscripts included in this special issue of the Brazilian Journal of Physical Activity and Health. We hope that, through these articles, readers can find resources for debates and the improvement of health strategies and promotion of programs and/or interventions aimed at physical education.

\section{References}

1. Malta DC, Silva MMA, Albuquerque GM, Lima CM, Cavalcante T, Jaime PC et al . A implementação das prioridades da Política Nacional de Promoção da Saúde, um balanço, 2006 a 2014. Ciênc Saúde Coletiva. 2014; 19(11): 4301-12.

2. Hallal PC, Dumith SC, Bastos JP, Reichert FF, Siqueira FV, Azevedo MR. Evolução da pesquisa epidemiológica em atividade física no Brasil: revisão sistemática. Rev Saúde Pública. 2007; 41(3): 453-60.

3. Ministério da Saúde. Política Nacional de Promoção da Saúde - PNPS: revisão da Portaria MS/GM nº 687, de 30 de março de 2006. Brasília: MS; 2015.

4. Malta DC, Castro AM, Cruz DKA, Gosh CS. A promoção da saúde e da atividade física no Sistema Único de Saúde. Rev Bras Ativ Física Saúde. 2008,13 (1): 24-7.

5. Knuth AG, Malta DC, Cruz DK, et al. Description of the Countrywide Physical Activity Network Coordinated by the Brazilian Ministry of Health: 2005-2008. J Phys Act Health. 2010, 7(Suppl 2), S253-8.

6. Silva RS, Silva I, Silva RA, Souza L, Tomasi E. Atividade física e qualidade de vida. Ciênc Saúde Coletiva. 2010; 15(1): 115-20.

7. Rodrigues JD, Ferreira DKS, SILVA PA, Caminha IO, Farias Júnior JC. Inserção e atuação do profissional de educação física na atenção básica à saúde: revisão sistemática. Rev Bras Ativ Física Saúde. 2013; 18(1): 5-15.

8. Guarda FRB, Silva RN, Araújo Júnior JLAC, Santos Neto PM. Incorporação e contribuições dos profissionais de educação física ao Sistema Único de Saúde do Brasil. Tempus, actas de saúde colet. 2014; 8(3):185-96.

9. ABRASCO. Produção científica brasileira sobre atividade física ganha destaque no cenário internacional. Disponível em: http://www.abrasco.org.br/site/2015/12/producaocientifica-brasileira-sobre-atividade-fisica-ganha-destaque-no-cenario-internacional. Acesso em: 14 de dezembro de 2015.

10. Freitas FF, Carvalho YM, Mendes VM. Educação Física e Saúde: aproximações com a "clínica ampliada". Rev Bras Ciênc Esporte. 2013; 35(3): 639-56.

11. Souza SC, Loch MR. Intervenção do profissional de educação física nos Núcleos de Apoio à Saúde da Família em municípios do norte do Paraná. Rev Bras Ativ Física Saúde. 2011; 16: 5-10.

12. Feitosa WMN. Programas de Promoção da Atividade Física: estudo de caso acerca da implementação Programa Academia da Cidade (PAC) em Recife entre 2002 e 2014. Tese (Doutorado em Saúde Pública) - Centro de Pesquisas Aggeu Magalhães, Fundação Oswaldo Cruz, Recife, 2015. 